\title{
ANALISIS SISTEM KEBIJAKAN PENGEMBALIAN KELEBIHAN PEMBAYARAN WAJIB PAJAK ORANG PRIBADI MELALUI RESTITUSI DAN KOMPESANSI DI KPP PRATAMA MANADO
}

\author{
Bryan S Lempas ${ }^{1}$, Treesje Runtu ${ }^{2}$, Rudy J Pusung ${ }^{3}$ \\ ${ }^{1,2,3}$ Fakultas Ekonomi dan Bisnis, Jurusan Akuntansi, Universitas Sam Ratulangi, Jl. Kampus Bahu, Manado, \\ 95115, Indonesia \\ E-mail : brayenlempss@gmail.com
}

\begin{abstract}
Tax is a source of revenue to finance all State expenditures including expenditures for development and expenditure in improving the welfare and quality of Human Resources (HR). The tax contribution in funding State expenditures continues to increase and requires support in the form of raising public awareness to meet its tax obligations. This research was conducted in Manado City, where this study aims to examine the return of overpayment. The research method used is descriptive analysis research. Result of research indicate that KPP Pratama manado give good service for taxpayer individual who apply for restitution of amount of tax debt paid by public also must know that even if money have entered to treasury state if proved there is more pay then State treasury also willing to reverse or compensate for other types of taxes. The refund of the tax payment is a refund of tax overpayment that has been assumed is really a tax that is more paid.

Keyword: Refund of overpayments, restitution, and compensation of individual taxpayers
\end{abstract}

\section{PENDAHULUAN}

Indonesia merupakan negara berkembang dengan rencana pembangunan nasional yang berkesinambungan. Dalam usaha mencapai tujuan tersebut, pemerintah menyiapkan tahap-tahap persiapannya, baik untuk jangka panjang, menengah, maupun jangka pendek, yang meliputi perencanaan, pembiayaan, pelaksanaan, pengawasan. Bagi Indonesia, pembangunan nasional membutuhkan sumber daya dan dana. Diperlukan dana yang besar untuk tetap mempertahankan laju pertumbuhan pembangunan yang konsisten dan menyeluruh.

Sektor pajak yang diberlakukan di Indonesia diantaranya adalah pajak penghasilan yang juga merupakan kontribusi terbesar dalam penerimaan pajak dalam negeri. Setiap tahun setelah tahun pajak berakhir, para wajib pajak akan memenuhi kewajibannya mengisi dan menyampaikan Surat Pemberitahuan Tahunan. Pajak penghasilan sudah beberapa kali mengalami perubahan undang-undang. Hal ini dimaksudkan untuk meningkatkan fungsi dan peranan perpajakan dalam rangka mendukung suatu kebijakan pembangunan nasional, khususnya di bidang ekonomi. Ketentuan mengenai hal tersebut diatur dalam Peraturan Menteri Keuangan Nomor 244/PMK.03/2008 tentang jenis jasa lain sebagaimana yang dimaksud dalam Pasal 23 Ayat (1) Huruf c Angka 2 Undang- Undang Nomor 7 Tahun 1983 tentang Pajak Penghasilan yang telah diubah terakhir dengan Undang- Undang Nomor 36 Tahun 2008.

Kebijakan atas restitusi atau pengembalian pajak kepada Wajib Pajak ini merupakan dilemma bagi para aparatur pajak karena pemberian restitusi dianggap sebagai pengeluaran Negara dan dapat membuka peluang potensi kerugian bagi kas Negara. Sistem ini menghendaki wajib pajak aktif, dimulai dari mendaftarkan diri ke Kantor Pelayanan Pajak (KPP) untuk mendapatkan nomor pokok wajib pajak (NPWP), menghitung jumlah pajak terutangnya, menyetorkan pajak terutangnya, hingga melaporkan penyetoran pajaknya. kondisi ini dapat memicu timbulnya kesalahan yang mungkin dibuat oleh wajib pajak adalah 
melakukan kesalahan hitung. Mengingat bahwa pada prinsipnya, pemerintah memungut pajak pada rakyat bukan untuk membebani, maka seandainya terjadi perbedaan penghitungan antara wajib pajak dan KPP, maka akan dilakukan penghitungan ulang, baik mengakibatkan kekurangan bayar atau adanya lebih bayar.

Berkait dengan keadaan seandainya wajib pajak tersebut merasa ada kelebihan, maka pemrintah harus mengembalikannya pada wajib pajak tersebut. Hal ini dapat dilakukan dalam bentuk restitusi maupun kompensasi. Intensitas yang melakukan pengembalian kelebihan pembayaran pajak dinilai cukup tinggi. Di dalam menunjukan bahwa pemerintah tidak hanya menuntut wajib pajak untuk membayar pajak tanpa adanya kekurangan, dimana kalau kurang harus menambah, namun disisi lain, pemerintah juga konsekuen apabila ada kelebihan dikembalikan pada wajib pajak karena itu adalah haknya. Berdasarkan masalah yang telah diuraikan, maka tujuan dari penelitian ini adalah untuk mengetahui system kebijakan pengembalian kelebihan pembayaran pajak melalui restitusi dan kompensasi.

\section{TINJAUAN PUSTAKA}

\subsection{Konsep Akuntansi}

\section{Akuntansi Perpajakan}

Waluyo (2013:35) menjelaskan bahwa menetapkan besarnya pajak terutang tetap mendasarkan laporan keuangan yang disusun oleh perusahaan, mengingat dalam ketentuan perundang-undangan perpajakan terdapat aturan-aturan khusus yang berkaitan dengan akuntansi, yaitu masalah konsep akuntansi dan peristiwa keuangan, metode pengukurannya, serta pelaporannya yang ditetapkan undang-undang

\subsection{Pajak}

Rochmat Soemitro, S.H., dikutip oleh Mardiasmo ( 2016 : 1), "mendefinisikan pajak adalah iuran rakyat kepada kas Negara berdasarkan undang - undang (yang dapat dipaksakan) dengan tidak mendapat jasa timbal balik (kontraprestasi) yang langsung dapat ditunjukkan dan yang digunakan untuk membayar pengeluaran umum". Edwin R.A Seligman dikutip oleh Waluyo ( 2013 : 2), "Tax is compulsory contribution from the person, to the government to defray the expenses incurred in the common interest of all, without reference to special benefit conferred", di mana pajak sebagai kontribusi wajib pajak kepada Negara untuk membiayai pengeluaran pemerintah untuk kepentingan umum dengan tidak mendapatkan imbalan secara langsung.

\subsection{Pengembalian Kelebihan Pembayaran Pajak}

Pengembalian Kelebihan Pembayaran Pajak baik itu pajak penghasilan (PPh), Pajak Pertambahan Nilai (PPN), atau Pajak Penjualan Barang Mewah (PPnBM), maupun Pajak Bumi dan Bangunan dilakukan apabila setelah diadakan penghitungan jumlah pajak yang sebenarnya terutang dengan jumlah kredit pajak menunjukkan jumlah selisih lebih ( jumlah kredit pajak lebih besar dari pada jumlah pajak yang terutang) atau telah dilakuka pembayaran pajak yang seharusnya tidak terutang.

\subsection{Restitusi}

Restitusi pajak yang seharusnya tidak terutang diatur secara khusus dengan Peraturan Menteri Keuangan nomor 10/PMK.03/2013 tentang Tata Cara Pengembalian Atas Kelebihan Pembayaran Pajak Yang Seharusnya Tidak Terutang. Menurut peraturan ini, Wajib Pajak dapat mengajukan permohonan pengembalian atas kelebihan pembayaran pajak yang seharusnya tidak terutang kepada Direktur Jenderal Pajak dalam hal:

1. Terdapat pembayaran pajak oleh Wajib Pajak yang bukan merupakan objek pajak yang terutang atau yang seharusnya tidak terutang. Pembayaran yang termasuk 
kelompok ini dapat berupa, pembayaran pajak oleh Wajib Pajak yang lebih besar dari pajak yang terutang, pembayaran pajak atas transaksi yang dibatalkan, pembayaran pajak yang seharusnya tidak dibayar, pembayaran pajak oleh Wajib Pajak terkait dengan permintaan penghentian penyidikan tindak pidana di bidang perpajakan sebagaimana dimaksud dalam Pasal 44B Undang-Undang KUP yang tidak disetujui.

2. Terdapat kesalahan pemotongan atau pemungutan yang mengakibatkan pajak yang dipotong atau dipungut lebih besar dari pada pajak yang seharusnya dipotong atau dipungut.

3. Terdapat kesalahan pemotongan atau pemungutan yang bukan merupakan objek pajak. Kesalahan yang termasuk kelompok ini dapat berupa, pemotongan atau pemungutan Pajak Penghasilan yang seharusnya tidak dipotong atau tidak dipungut, pemungutan Pajak Pertambahan Nilai yang seharusnya tidak dipungut, atau pemungutan Pajak Penjualan atas Barang Mewah yang seharusnya tidak dipungut.

4. Terdapat kelebihan pembayaran pajak oleh Wajib Pajak yang terkait dengan pajakpajak dalam rangka impor. Kelebihan pembayaran pajak yang terkait dengan pajakpajak dalam rangka impor meliputi Pajak Penghasilan Pasal 22 impor, Pajak Pertambahan Nilai impor, dan/atau Pajak Penjualan Barang Mewah impor yang telah dibayar dan menyebabkan terjadinya kelebihan pembayaran pajak..

Terhadap permohonan resitusi karena pajak yang seharusnya tidak terutangini, kantor pajak akan melakukan verifikasi. Verifikasi ini adalah prosedur baru di DJP setelah terbitnya Peraturan Pemerintah nomor 74 Tahun 2011. Menurut definisinya, verifikasi adalah serangkaian kegiatan pengujian pemenuhan kewajiban subjektif dan objektif atau penghitungan dan pembayaran pajak, berdasarkan permohonan Wajib Pajak atau berdasarkan data dan informasi perpajakan yang dimiliki atau diperoleh Direktur Jenderal Pajak, dalam rangka menerbitkan surat ketetapan pajak, menerbitkan/menghapus Nomor Pokok Wajib Pajak dan/atau mengukuhkan/mencabut pengukuhan Pengusaha Kena Pajak.

Dalam hal untuk melakukan verifikasi diperlukan tambahan dokumen pendukung lainnya yang terkait dengan permohonan pengembalian atas kelebihan pembayaran pajak yang seharusnya tidak terutang, DJP dapat meminta dokumen tersebut kepada Wajib Pajak. Biasanya dokumen-dokumen yang perlu adalah bukti pembayaran pajak seperti Surat Setoran Pajak (SSP). Bisa juga Surat Pemberitahuan Pajak baik SPT Badan jidak terkait PPh maupun SPT Masa PPN. Jika semuanya sudah sesuai ketentuan yang berlaku, maka akan diterbitkan SKPLB (surat ketetapan pajak lebih bayar).

\subsection{Kompensasi}

Kompensasi ( pegimbangan) Misalnya, kalau pajak tahun yang lalu terdapat kelebihan pembayaran maka kelebihan tersebut dapat digunakan atau dikompensasikan dengan utang pajak tahun berikutnya (kompensasi horizontal). Atau kompensasi vertikal yaitu kelebihan pembayaran pada jenis pajak tertentu diimbangkan dengan utang pajak lainnya pada tahun yang sama.

\section{METODE PENELITIAN}

\subsection{Jenis Penelitian}

- Penelitian ini termasuk pada jenis penelitian deskriptif. Mendefinisikan bahwa penelitian deskriptif merupakan jenis penelitian yang tujuannya untuk menyiapkan gambaran lengkap mengenai setting social atau hubungan antara fenomena yang diuji. Metode deskriptif yaitu metode yang digunakan untuk menggambarkan atau menganalisis suatu hasil penelitian tetapi tidak digunakan untuk menggunakan kesimpulan yang lebih luas (Sugiyono 2012:21). 


\subsection{Tempat dan Waktu Penelitian}

Penelitian ini dilaksanakan pada KPP Pratama Manado yang beralamat di Jalan Gunung Klabat Kotak Pos 23, Manado 95117 Sulawesi Utara. Waktu penelitian dari bulan Juni sampai bulan September 2017.

\section{Metode analisis}

Metode analisis yang digunakan dalam penelitian ini adalah metode analisis deskriptif. Metode analisis deskriptif merupakan metode yang digunakan untuk menggambarkan dan menganalisis suatu hasil penelitian tetapi tidak digunakan untuk membuat kesimpulan yang lebih luas (Sugiyono, 2012: 21). Dalam penelitian ini metode analisis deskriptif yang akan diterapkan untuk mengenalisis Sistem kebijakan pengembalian kelebihan pembayaran Wajib Pajak Orang Pribadi Melalui Restitusi dan Kompensasi di KPP Pratama Manado.

\section{HASIL PENELITIAN DAN PEMBAHASAN}

\subsection{Hasil Penelitian dan Pembahasan}

\section{Sistem Kebijakan Pengembalian Kelebihan Pembayaran Pajak}

Kebijakan pengembalian kelebihan pembayaran pajak kepada wajib pajak yang memenuhi persyaratan tertentu yang diatur dalam UU KUP Pasal 17D dan peraturan Menteri Keuangan Nomor 198/PMK.03/2013 sebagaimana telah mengalami perubahan dari PMK Nomor 193/PMK.03/2007dan PMK Nomor 54.03/2009, ada tiga hal perubahan yang diatur dalam peraturan Menteri keuangan yaitu:

1. Perubahan atas ketentuan wajib pajak mana saja yang dapat diberikan pengembalian kelebihan pembayaran pajak.

Pada Peraturan Menteri KeuanganNomor 193/PMK.03/2007 Ketentuan wajib pajak yang termasuk dalam wajib pajakyang memenuhi persyaratan tertentu adalah sebagai berikut:

1. wajib pajak orang pribadi yang menjalankan usaha atau pekerjaan bebas yang menyelenggarakan pembukuan dengan:

- jumlah peredaran usaha yang tercantum dalam SPT Tahunan Pajak Penghasilan paling banyak sama dengan batasan peredaran usaha wajib pajak orang pribadi yang diperbolehkan menghitung penghasilan neto dengan menggunakan norma penghitungan penghasilan neto.

-Jumlah Lebih Bayar Menurut SPT Tahunan Pajak Penghasilan kurang dari Rp. 1.000.000.00 (satu juta rupiah)

-Jumlah Lebih Bayar Menurut SPT Tahunan Pajak Penghasilan paling banyak 0,5\% dari jumlah peredaran usaha.

2. wajib pajak dimana jumlah peredaran usaha yang tercantum dalam SPT Tahunan Pajak Penghasilan paling banyak Rp. 5.000.000.000,00 (lima miliar rupiah) dan jumlah lebih bayar menurut SPT Tahunan Pajak Penghasilan kurang dari Rp 10.000.000,00 (sepuluh juta rupiah).

3. Pengusaha Kena Pajak dimana jumlah penyerahan menurut SPT Masa Pajak Pertambahan nilai untuk suatu masa pajak paling banyak Rp. 150.000.000,00 (seratus lima puluh juta rupiah) dan memiliki jumlah lebih bayar paling banyak Rp. 150.000,00 (seratus lima puluh rupah).

Dalam Peraturan Menteri Keuangan 54/PMK.03/2009 Kententuan Wajib Pajak yang termasuk dalam wajib pajak yang memenuhi persyaratan tertentu hanya terdapat perubahan pengusaha kena pajak dimana jumlah penyerahan menurut SPT MasaPajak Pertambhan nilai untuk suatu Masa paling banyak Rp. 400.000.000,00 (empat ratus juta rupiah) dan memiliki jumlah lebih bayar paling banyak Rp. 28.000.000,00 (dua puluh delapan juta rupiah) perubahan terakhir dalam Peraturan Menteri Keuangan 
Nomor 198/PMK.03/2013 Pasal 2 yang menjadi wajib pajak yang memenuhi persyaratan tertentu adalah:

1.Wajib Pajak orang pribadi orang pribadi yang tidak menjalankan usaha atau pekerjaan bebas yang menyampaikan SPT Tahunan PajakPenghasilan lebih bayar restitusi.

2. Wajib Pajak Orang Pribadi yang menjalankan usaha atau pekerjaan bebas yang menyampaikan SPT Tahunan Pajak Penghasilan lebih bayar restitusi dengan jumlah lebih bayar paling banyak Rp.10.000.000,00 (sepuluh juta rupiah)

3. Wajib Pajak Badan yang menyampaikan SPT Tahunan Pajak Penghasilan lebih bayar restitusi dengan jumlah lebih bayar paling banyak Rp.100.000.000,00 (seratus juta rupiah)

4. Pengusaha Kena Pajak yang menyampaikan SPT Masa Pajak Pertambahan Nilai lebih bayar restitusi dengan jumlah lebih bayar paling banyak Rp.100.000.000,00 (seratus juta rupiah)

Ambang batas jumlah lebih bayar yang tercantum dalam SPT wajib pajak dalam kebijakan pengembalian kelebihan pembayaran pajak kepada wajib pajak yang memenuhi persyaratan tertentu ini mengalami perubahan dikarenakan adanya pertimbangan bahwa dengan menaikkan ambang batas lebih bayar maka SPT-SPT Lebih bayar yang disampaikan oleh wajib pajak yang akan diproses dengan pemeriksaan akan semakin berkurang. Hal ini disebabkan karena jumlah pengawai fungsional pemeriksa hanya terbatas sedangkan untuk SPT Lebih bayar yang dilaporkan oleh wajib pajak jumlahnya sangat banyak.

Hal ini bila dikaitkan dengan teori cost of taxation terutama pada indicator time cost, akan menghemat waktu bagi pemeriksa dlam memeriksa SPT lebih bayar sehingga waktu tersebut dapat digunakan bagi pemeriksa untuk memeriksa SPT Nihil atau SPT Kurang bayar yang sebenarnya lebih berpotensi dalam meningkat penerimaan Negara dari sumber pajak. Selain itu Kpp juga memiliki pertimbangan bahwa wajib pajak yang melaporkan SPT lebih bayar cenderung memiliki tingkat kepatuhan yang lebih tinggi dibandingkan dengan wajib pajak yang melaporkan SPT nya dengan kondisi nihil atau kurang bayar.

Pada saat wajib pajak melaporkan SPT lebih bayar, biasanya wajib pajak tersebut menyadari bahwa mereka akan diperiksa. Wajib pajak tersebut sudah mempersiapkan segala sesuatunya seperti pembukuan dan bukti-bukti yang memperkuat bahwa SPT mereka benar-benar dalam kondisi lebih bayar sehingga pada saat dilakukan pemeriksaan, pemeriksa hanya sedikit menemukan bukti-bukti apabila terjadi indikasi pelanggaran. Oleh karena itu, atas pemeriksaan SPT lebih bayar tidak memberikan hasil yang signifikan bagi penambahan penerimaan Negara. Atas pertimbangan-pertimbangan yang telah disebutkan maka Kpp mengubah kebijakan dengan menaikkan ambang batas jumlah lebih bayar yang memperoleh pengembalian kelebihan bayar.

2. Jangka waktu pemprosesan atas permohonan pengembalian kelebihan pembayaran pajak.

Pada peraturan sebelumnya disebutkan bahwa Kpp setelah melakukan penelitian atas permohonan pengembalian kelebihan pembayaran pajak dari wajib pajak yang memenuhi peryaratan tertentu, menerbitkan Surat Keputusan Pengembalian kelebihan pajak :

- Paling lama 3(tiga) bulan sejak permohonan diterima secara lengkap untuk pajak penghasilan.

- Paling lama 1 (satu) bulan sejak permohona diterima secara lengkap untuk pajak pertambahan nilai.

Sedangkan pada perubahan terakhir berdasarkan hasil penelitian, Kpp menerbitkan Surat Keputusan Pengembalian Kelebihan pajak paling lama : 
- 15 ( lima belas) hari kerja sejak permohonan diterima secara lengkap, untuk permohonan pengembalian kelebihan pembayaran pajak penghasilan orang pribadi

- 1 (satu) bulan sejak permohonan diterima secara lengkap, untuk permohonan pengembalian kelebihan pembayaran pajak penghasilan badan.

- 1 (satu) bulan sejak permohonan diterima secara lengkap, untuk permohonan pengembalian kelebihan pembayaran pajak pertambahan nilai.

Pertimbangan atas perubahan pemprosesan jangka waktu pengembalian kelebihan pembayaran pajak ini diharapkan bahwa Kpp dapat memberikan pelayan yang terbaik bagi wajib pajak dimana Kpp berusaha untuk menyeimbangkan kewajiban wajib pajak dalam membayar pajak dan hak wajib pajak salah satunya yaitu pengembalian kelebihan pembayaran pajak sebagai konsekuensi dari sistem pemungutan yang dianut di Indonesia yaitu self assessment system.

3. Dasar Pemprosesan atas permohonan pengembalian kelebihan pembayaran pajak.

Dasar Pemprosesan Pasal 17 D UU KUP pada Peraturan sebelumnya hanya wajib pajak yang memilih untuk mengajukan permohonan restitusi pada SPT lebih bayar dan memilih kolom Pasal 17 D UU KUP dengan pengembalian pendahuluan, tetapi dengan peraturan yang sekarang wajib pajak yang akan diproses dengan pasal 17 D UU KUP adalah Wajib Pajak yang memang untuk mengajukan permohonan restitusi pada SPT lebih bayar dan memilih kolom Pasal 17 D UU KUP dengan pengembalian pendahuluan, wajib pajak yang memilih untuk mengajukan permohonan restitusi pada SPT lebih bayar dan memilih kolom Pasal 17 B UU KUP, dan wajib pajak yang memiliki SPT lebih bayar tetapi tidak memilih mengajukan restitusi maupun kompensasi ke masa pajak berikutnya sepanjang lebih bayarnya tidak melebihi ambang batas yang telah ditentukan dalam peraturan Menteri Keuangan Nomor 198/PMK.03/2013Pasal 2.

Karena adanya unsur paksaan bagi wajib pajak yang melaporkan SPT lebih bayarnya tetapi tidak melebihi ambang batas yang telah ditentukan, maka Kpp atas permohonan wajib pajak dapat memberikan keringanan atas sanksi apabila suatu saat diperiksa ditemukan adanya bukti bahwa SPT lebih bayar tersebut tidak benar dan diterbitkan Surat Ketetapan Pajak Kurang Bayar. Berdasarkan Pasal 36 UU KUP dan peraturan Menteri Keuangan Nomor 198/PMK.03/2013 Pasal 12, Kpp karena jabatan atau atas permohonan wajib pajak, dapat memberikan pengurangan atau penghapusan sanksi administrasi sehingga sesuai dengan Pasal 13 UU KUP besarnya sanksi administrasi 2\% (dua persen) per bulan paling lama 24 (dua puluh empat bulan) menjadi paling banyak $48 \%$ (empat puluh delapan persen) dimana dengan peraturan sebelumnya dikenakan sanksi $100 \%$ (seratus persen) dan tidak ada pengurangan sanksi.

Selain ada pengurangan sanksi administrasi, kebijakan yang terdahulu, apabila jumlah lebih bayar yang ditetapkan oleh wajib pajak tidak akan berbeda dengan yang ada di sistem atau data base yang dimiliki oleh direktur jenderal pajak, maka atas jumlah lebih bayar yang ditetapkan oleh wajib pajak tidak akan diterbitkan Surat Keputusan Pengembalian Kelebihan pajak. Berbeda dengan kebijakan yang sekarang apabila yang sekarang apabila jumlah lebih bayar yang ditetapkan oleh wajib pajak tidak sesuai dengan pada sistem atau data base yang dimiliki oleh direktur jenderal pajak maka atas jumlah lebih bayar yang ditetapkan wajib pajak akan diterbitkan Surat Keputusan Pengembalian kelebihan pajak terlebih dahulu. Atas Surat KeputusanPengembalian Kelebihan Pajak tersebut akan dipantau sampai dengan 3 (tiga) bulan, jika selisih antara jumlah lebih bayar yang ditetapkan oleh wajib pajak sudah sama dengan jumlah lebih bayar yang terdapat system atau data base yang dimilki oleh Direktur Jenderal Pajak maka proses pengembalian kelebihan pembayaran pajak sudah selesai. Namun apabila selisih tersebut pada akhirnya tidak sama maka atas Surat Keputusan Pengembalian Kelebihan pajak yang sudah diterbitkan akan diajukan pembetulan sesuai Pasal 16 UU KUP. 


\section{Prosedur Pelaksanaan Restitusi dan Kompensasi di Kantor Pelayanan Pajak Pratama Manado}

Apabila wajib pajak merasa bahwa ada kelebihan atas pembayaran utang pajak yang sudah dilakukan, maka yang bersangkutan harus meminta pengembalian ke Kas Negara melalui Kantor Pelayanan Pajak. Adapun prosedurnya adalah :

1. Menyertakan SPT yang wajib pajak laporkan.

2. Mengusulkan pada Kanwil usulan pemeriksaan atas SPT Lebih Bayar. Harus diperiksa karena harus bertanggung jawab kepada Kantor Kas Negara yang artinya harus bertanggung jawab kepada masyarakat. Hal ini untuk mengetahui, apakah benar terjadi lebih bayar, mengingat telah menggunakan self assessment system, di mana penghitungannya telah dilakukan oleh wajib pajak sendiri. Selanjutnya dokumen terkait yang dipakai sebagai dasar pemeriksaan setelah permohonan pemeriksaan disetujui oleh Kanwil meliputi: PTKP, semua harta yang dimiliki, utang kewajiban. Bisa saja terjadi bahwa lebih bayar itu karena salah hitung. Dalam hal ini account representative yang bertanggung jawab terhadap wajib pajak di wilayahnya, melakukan pendekatan, menghimbau apa data sudah benar. Kalau ada yang belum dilaporkan, dihimbau untuk dilaporkan.Setelah itu pemeriksaan dilanjutkan

\section{Kendala dalam pelaksanaan restitusi dan kompensasi serta solusi}

Pada prinsipnya tidak ada kendala atau kesulitan dalam pelaksanaan pengembalian kelebihan pembayaran pajak sepanjang persyaratan yang diperlukan untuk itu terpenuhi. Namun demikian, KPP Pratama Manado senantiasa berusaha untuk memberikan pemahaman kepada masyarakat berkait dengan proses yang harus dijalankan. Seperti misalnya kalau atas penghitungan ulang oleh Wajib Pajak terdapat lebih bayar namun jumlahnya sangat sedikit dan dirasa tidak imbang dengan proses yang harus dilalui, maka disarankan untuk tidak melanjutkannya pada proses pemeriksaan, karena hal tersebut nantinya akan memakan waktu yang mungkin hal tersebut dapat menimbulkan kerugian lain bagi yang bersangkutan. Misalnya harus meluangkan waktu menjawab pertanyaan dari petugas, yang mungkin waktunya itu dapat dipakai untuk menjalnkan perusahaan, sementara selisih itu jumlahnya sangat kecil. Sejak awal, petugas dapat memprediksi apakah itu termasuk pemeriksaan kantor atau lapangan, sehingga petugas dapat memberikan nasihatnya.

KPP Pratama Wilayah Manado selalu merespon baik atas adanya laporan dari Wajib Pajak yang menyatakan bahwa terdapat kelebihan pembayaran pajak. Di mana hal tersebut biasanya terjadi karena Wajib Pajak :

1. Dokumen tidak ada. Pencatatan maupun pembukuan sering tidak dilakukan secara rutin.

2. Adanya percampuran rekening antara milik pribadi dengan perusahaan.

Atas kondisi tersebut, sekalipun Wajib Pajak sudah melaksanakan self assessment system, namun masih sering terjadi setelah penyetoran pembayaran utang pajak, disadari bahwa terdapat kelebihan bayar. Untuk itu maka KPP Pratama Manado mengadakan pembinaan kepada Wajib Pajak supaya lebih patuh, dengan cara antara lain mengajarkan supaya Wajib Pajak mengadakan pembukuan lebih baik dan pembayaran sesuai ketentuan. KPP Pratama Manado juga mengadakan sosialisasi untuk memberikan pengetahuan kepada Wajib Pajak baru berkait dengan hak dan kewajiban dan mensosialisasikan ketentuan-ketentuan baru. Berdasar data yang ada, bisa diajukan, Statistik Penyelesaian Restitusi di KPP Pratama Manado adalah sebagai berikut 
Tabel 4.2

Data SKPLB dan SKPLB

\begin{tabular}{|l|l|l|l|l|l|}
\hline \multirow{2}{*}{} & \multirow{2}{*}{ Tahun } & \multicolumn{2}{|l|}{ SKPLB } & \multicolumn{2}{l|}{ SKPKB } \\
\cline { 3 - 6 } & Jumlah & Nominal & Jumlah & Nominal \\
\cline { 2 - 6 } & 2014 & 22 & 19.768 .425 .818 & 266 & 32.946 .515 .184 \\
PPH & & & 11.477 .523 .923 & 430 & 43.866 .731 .842 \\
\cline { 2 - 6 } & 2015 & 18 & 57.629 .194 .301 & 259 & 14.513 .720 .241 \\
\cline { 2 - 6 } & 2016 & 22 & 88.875 .144 .042 & 955 & 91.326 .967 .267 \\
\cline { 2 - 6 } & jumlah & 62 & & & \\
\hline
\end{tabular}

Sumber: SubBagian Umum Kpp PratamaManado

Ini menunjukkan bahwa KPP Pratama Manado memberikan pelayanan yang baik bagi Wajib Pajak yang mengajukan restitusi atas jumlah utang pajak yang telah dibayar, dan menunjukkan bahwa KPP Pratama Manado serius dalam menerima laporan masyarakat, tidak mempersulit. Ini juga sebagai sarana untuk menunjukkan adanya keseimbangan antara hak dan kewajiban, bahwa Wajib Pajak tidak hanya dituntut untuk membayar utang pajaknya tepat waktu, namun juga seandainya Wajib Pajak merasa terdapat lebih bayar atas utang pajak yang telah dibayar, KPP Pratama Manado menanggapinya dengan serius dan memprosesnya. Masyarakat juga harus tahu, bahwa sekalipun uang sudah masuk ke Kas Negara apabila terbukti bahwa ada lebih bayar, maka Kas Negara juga bersedia mengembalikannya atau melakukan kompensasi pada jenis pajak yang lain.

\section{KESIMPULAN DAN SARAN}

\subsection{Kesimpulan}

Berdasarkan hasil penelitian dan pembahasan yang dilakukan, peneliti menarik kesimpulan sebagai berikut.

1. Sistem kebijakan pengembalian kelebihan pembayaran pajak ini telah memenuhi prinsip dasar pemungutan pajak, yaitu kesederhanaan, keadilan dan efisiensi. Kebijakan ini menjamin keadilan dengan menyaring semua permohonan sesuai Pasal 17D, sehingga kecenderungan Wajib Pajak dalam memilih jalur pengembalian kelebihan pembayaran pajak sesuai keinginannya.

2. KPP Pratama Manado memberikan pelayanan yang baik bagi Wajib Pajak yang mengajukan restitusi dan kompensasi atas jumlah utang pajak yang telah dibayar, dan menunjukkan bahwa KPP Pratama Manado serius dalam menerima laporan masyarakat, tidak mempersulit.

3. Untuk menunjukkan adanya keseimbangan antara hak dan kewajiban, bahwa Wajib Pajak tidak hanya dituntut untuk membayar utang pajaknya tepat waktu, namun juga seandainya Wajib Pajak merasa terdapat lebih bayar atas utang pajak yang telah dibayar, KPP Pratama Manado menanggapinya dengan serius dan memprosesnya.

\subsection{Saran}

KPP Pratama Manado hendaknya lebih banyak lagi melakukan sosialisasi tentang sistem kebijakan dan prosedur pengembalian kelebihan pembayaran pajak baik melalui restitusi maupun kompensasi kepada seluruh lapisan masyarakat, tidak 
saja pada Wajib Pajak yang mengajukan permohonan pemeriksaan, namun bisa juga kepada wajib pajak secara keseluruhan dan masyarakat pada umumnya. Hal ini karena dalam masyarakat masih terdapatanggapan bahwa kalau Wajib Pajak sudah melakukan pembayaran utang pajak, dan setelah dihitung ulang ternyata terdapat lebih bayar, mengira tidak dapat diproses untuk pengembalian, sementara secara teori ada hak dan kewajiban Wajib Pajak maupun KPP Pratama Manado. Hal ini harus dipahami oleh masyarakat, untuk semakin meningkatkan kesadaran perpajakan.

\section{DAFTAR PUSTAKA}

Atiman jacobus, 2011, Pengaruh Kepatuhan wajib pajak dan pengetahuan teknis perpajakannya terhadap kesediaan wajib pajak orang pribadi membayar pajak penghasilan.

Andi, 2015. Perpajakan Indonesia.Penebit CV ANDI OFFSET. Yogyakarta.

Agus, Raden. 2014. Catatan Perpajakan. http://pajaktaxes.blogspot.co.id/p/resitusi.html

Bahri, Syaiful. 2016. Pengantar Akuntansi. Penerbit Andi. Yogyakarta

Boone, Khurana, Raman, 2013. Religiosity and Tax Avoidance.Journal Of American Taxation Association Volume35 issues 1 pages 53-84.

Dita Amalia Dastia Fitri, 2015, Evaluasi impelementasi Kebijakan pengembalian kelebihan pembayaran pajak bagi wajib pajak badan yang memenuhi persyaratan tertentu.

Elbakry, Ashraf, Jacinta C. Nwachukwu, Hussein A. Abdou, dan Tamer Elshandidy, 2017. "Comparative Evidence On The Value Relevance OF IFRS-Based Accounting Information In Germany And The UK'. Journal of international Accounting, Auditing and Taxation 28 (2017), 10-30.

Francis Pol C. Lim, 2013. Impact Of Information Technology On Accounting System. Journal Of Multimedia Services Convergent with art, Humanities and Sociology Vol. 3 (2):93-106.

Harnanto. 2013. Perencanaan Pajak, Edisi Pertama,Penerbit BPFE. Yogyakarta

Ilyas, Wirawan B, dan Richard Burton, 2011. Hukum Pajak, Edisi Kelima. SalembaEmpat, Jakarta

Ilyas,Wirawan \& Burton, Richard. 2013.Hukum Pajak, Cetakan Kedua, Salemba Empat, Jakarta.

Indrawan, Rully danYaniawati, Poppy, 2014. Metodologi Penelitian Kuantitatif Dan Kualitatif, dan Campuran untuk Manajemen, Pembangunan dan Pendidikan. PT. Refika Aditama. Bandung 